\title{
COMPARATIVE ANALYSIS OF INTELLIGENT DEVIL VILLAINS IN W. SHAKESPEARE'S TRAGEDIES: MACBETH, JULIUS CAESAR AND OTHELLO
}

\author{
CTursunova M., ORCID: 0000-0002-3552-4547, Uzbek State World languages University, \\ Tashkent, Uzbekistan, mukhlisa_vakhobovna@mail.ru
}

\section{СРАВНИТЕЛЬНЫЙ АНАЛИЗ ЗЛОДЕЕВ В ТРАГЕДИЯХ У. ШЕКСПИРА «МАКБЕТ», «ЮЛИЙ ЦЕЗАРЬ» И «ОТЕЛЛО»}

\author{
(CTурсунова M. B., ORCID: 0000-0002-3552-4547, Узбекский государственньій университет \\ мировых языков, г. Ташкент, Узбекистан, mukhlisa_vakhobovna@mail.ru
}

Abstract. This article compares three prominent villains - Macbeth, Brutus and Iago in three famous tragedies: Macbeth, Julius Caesar and Othello by William Shakespeare according to the terms of intelligence and devilry. These two main aspects are considered for the analysis to find the main similarities and differences and categorize their villainy on the basis of devilry.

Аннотащия. В этой статье сравниваются три выдающихся злодея - Макбет, Брут и Яго в трех знаменитых трагедиях Уильяма Шекспира «Макбет», «Юлий Цезарь» и «Отелло» в соответствии с понятиями интеллекта и злодейства. Эти два основных аспекта рассматриваются для анализа основных черт сходства и различия исходя из их дьявольской природы.

Keywords: villain, villainy, devilry, ambition, conspiracy.

Ключевые слова: злодей, злодейство, дьявольщина, амбиция, заговор.

The following names of villains sealed the name - Shakespeare as the greatest playwright ever lived on earth. These names are popular not only among the literary men but also among the ordinary people. They are Iago, Macbeth and Brutus. We assume their devil like evil spirit made us to categorize them as intelligent devil villains. As far as the notion of devil exists, the villainous names above persist in people's lives. Devil - a personal supreme spirit of evil often represented in Jewish and Christian belief as the tempter of humankind, the leader of all apostate angels, and the ruler of hell (https://www.merriam-webster.com/dictionary/devil). Therefore, from this definition we can infer that first and most of all devil villains are the ones who are engulfed with supreme spirit of evil, which creates a hell on earth. The psychologists say that people consist of three pair components that make them who they are. They are body - stomach, brain - mind and heart - soul. More importantly and more specifically, they need to be fed to be kept in a persistent action. Men fill their stomach to keep their body alive, fill their mind with particular information to keep their brain active mechanically and at last encompass their hearts with feelings, which are emerged by the result of their deeds. Thus, devil like villains fill their soul with the emotions, which arise through the result of the highest evil misdeeds. Moreover, we have to mention that when evil spirit finds harmony with superior intelligence it prospers in limitless scope. This kind of villains almost ever "dominates and controls the action of the play and shares a unique intimacy with the audience" [7, 9] which helps us to make it as a following significant feature of devil villains. Least and 
foremost, we have to state that despite their immoral nature they turn attractive, charming and seductive both to the audience and to the other characters because "these villains transcend human capacity for intellect, perception, and persuasion, and at their worst, they become unstoppable tyrants, killers, and psychological tormenters". [7, 9] Also, "The Devil represents the idea of the act of deception requiring the avoidance of scrutiny and dependence upon the maintenance of a falsely perceived reality". [8, p. 41] And this kind of falsely perceived reality for instance, in "Macbeth" can hundred percent lead to the destruction of his own.

Before going further and deeper we have to identify whom we consider a villain and why. It would rather be fair if we started our analysis with the villainy of Macbeth in the tragedy of "Macbeth" - the one who is attracted due to his ambitiousness. "His passion for power and his instinct of self-assertion are so vehement that no inward or outward misery could persuade him to relinquish the fruits of crime, or to advance from remorse to repentance". [4, p. 188] Obviously, in this tragedy, Shakespeare informs us that those who are great can be destroyed by focusing on their negative inner qualities. Even the bravest and most loyal militaries can be corrupted by evil under some influence that they appear to be. It means every person can have an inhuman quality but only the people who are firmly determined are capable of avoiding the infusion of wicked people in their lives. Apparently, Macbeth's disappointment because of not being valued highly was likely taken advantage of. Here is one thing we find it necessary to mention to those who still think that Macbeth is partially cannot be considered a villain, or else a devil villain. He is a villain who gave a conscious way to villainy inside him. Moreover, "Satan and Macbeth present common characteristics in their heroic qualities" [5, p. 334] because there are two talented instruments of evil, and both are very active and strong instruments of mischief and destruction. Furthermore, we claim when Parker stated "The play...is not the story of a villain, but of a good man who terrifyingly collapses - morally, psychologically, and spiritually" [6, p. 21] was mistaken because a good man never collapses in a final destination. Maybe for some extent he is not a typical villain but he naturally became the victim of his own wrong decisions. Because devil villains are not born villains like monster villains. Devil villains become it. And, Shakespeare's rightly chosen atmosphere for this play can also prove our words. "The atmosphere of Macbeth was gloomy, black, and fearful essentially due to the murderous and destructive nature of the actions of Macbeth". [2, p. 169] This is the appropriate condition made up for a devil villain.

Most admittedly, Iago (in "Othello") and Macbeth have something in common. They both lack the utmost power. Their potential hasn't met the appropriate status or reward as they expected. By the way, Iago is the most memorable evil of all the villains in literature that has ever been embodied. No devil or evil spirited can be equal to him. He is unique. He is ideal. He so slyly accomplishes his objectives that the audience feel deprived of any sympathy for him. The reason for it can be that he targets a loyal innocent woman, Desdemona as an essential tool to guarantee his success. Definitely, nobody would argue in the claim of Iago's thinking and acting like a devil. While analyzing the work of some critics we came across with some notions which confirm our claim of Iago as a devil villain. Iago delights in villainy for villainy's sake. While his malignity is not motiveless, the motive is entirely inadequate to explain his actions. In "Othello", the factors that motivate him to hurt other characters are based on his idealistic and unrealistic expectations about life. He is just unreasonable in his action to disgrace Othello's wife, simply because he suspects that Othello has had an affair with his wife. Throughout the story, it is clear that "the villain's actions are unreasonable although he tries to justify them with motives". [1, p. 78]

If we emphasize intelligence as another mark of the rational villain, then our next villain character may be an intellectual without embracing a rationalistic way of life. Brutus, for example, appears to be an admirable individual who is both intelligent and introspective. And yet, W.R. 
Bowden, famous English literary critic of the last century, disagrees with those who describe Brutus as "an intellectual" [3, p. 48] which we think is a fair claim because whatever tricks a villain uses to manipulate his crime, it cannot relieve him from the deceitful consequences of his misdeeds. Yet, at the same time, his masterful talent of directing his wit towards his conspiracy proves that he is not a mere stupid. He is blatantly accustomed to living in his strong motives. Though, we consider Brutus as an intellectual we feel like to prove him as a devil villain. He is simply a devil villain because he is not weak and passive acting in his evil engagements. He is a devil villain because his villainous tool is his intelligence that like a strong self - driven mechanism gives him a hand to act consciously and confidently. Due to his glorious intellectual being and healthy mind he is never hesitated in his decisions. While comparing these three villains, Macbeth, Brutus and Iago, we might assuredly state that they weren't rulers but were eager to become one, they were initially loyal to their rulers but their loyalty was for the sake of another higher status and they were able to find some factors to manipulate their misdeeds to be acquitted.

In further comparison we would say, Macbeth lacked self-drive, and his drive was his wife Lady Macbeth. In case of Iago however we have to mention one intrinsic fact that throughout one play, Iago is the only villain. He manages everything by himself, by his cunning and deceitful mind and evil heart. And of course, overall the analysis we could see reasonable similarities and distinctive features between villains. But the overall morality is that what or how much criticism they receive, villains are villains. They feed their souls with their immorality, sins, corruption, and sufferings of other people. They are forever bursting for the desire of something they have no heart. They are discontent, dissatisfied with what they already possess, physically, mentally or materialistically. They want more and they ever need more: more power, more killing, more fame, more honor, more pain, in short more of the persuasion of their desires. After a moderately thorough investigation of villains in Shakespeare's different plays, such as comedies, histories and tragedies, we are to confess seriously that villain characters are literally well thought and perfectly created characters. Although, we have seen the primary character of villains in the literature of ancient Greek and Roman, we claim that the true image of villains emerged in the English Renaissance due to the contribution of Christopher Marlowe and highly essential productive work of William Shakespeare, who put a milestone to the image of a villain. Genius Shakespeare gave a true shape to a villain character with human attributes which still fascinates Shakespeare's readers. Tragic villains - villains who stand out from their plays by the ingeniousness of their mind, by the hyper evil intellectuality driving them towards unprecedented misdeeds, by the magnitude of the image of their singular and sophisticated cunning devilry, by artistic performance of their crimes without inclination to making mistakes and by their ability - effectively take control of the course of the play. Tragic villains are therefore tragic that they expose the peak of human corruptness and evil heart that never repents. The consequences of their destructive power and misdeeds can be even after they die, heroes feel the pain left behind. This impact can also be found in the audience. Through the depiction of tragic villains we feel like to consider the consequences of our steps more strongly. And that's why, when we compare strong tragic villains - more exactly Devil villains, to some other types villains, specifically to the villains in histories and monster villains we slightly start to perceive that Devil villains are not immoral villains they maturely have high morals which they almost ever follow but at the same time can break these moral codes for their own benefits. Since the humankind was created, it has fought against evil or vice because evil is the opposite of humanity, the deviation from that which is natural for humankind, yet evil originates in the human heart. The human soul cannot endure any form of evil. One way or another evil destroys the soul. Evil is incompatible with humanity. Evil is evil in what way you present it, like Richard III by proving to be villain because your deformation prevents you from becoming someone you are 
expected to be or like Edmund by manipulating your villainy due to your illegitimacy considering that the destiny made you a victim so that you are inclined to take revenge from your father, or else like Iago by thinking that you deserve more than you are given and the one who possessed everything you had a right for, or like Juliet's father by affirming your daughter that you have a total superiority over her because you brought her up, gave her everything that belongs to you, or like Brutus by insisting on that your conspiracy is arranged just for the prosperity of the republic, or like Macbeth by plotting against the one who gave you a right to become a Thane of Cawdor just because you haven't been rewarded appropriately and your contribution is not taken into account, or at least like Brutus by reckoning that you have nothing to do with the ones who have different beliefs.

From our analysis above we can make a definite statement that the genius playwrights of the Renaissance created effective villains. And, we have to bear in mind that effective villains are intelligent. However, this does not necessarily mean that they are intellectually gifted. Rather, it means that they avoid making stupid decisions. They are highly experienced in making straight decisions. We have to strongly confess that a truly great villain is always two steps ahead of the hero, and carefully considers every option. This does not mean that they are above making mistakes. Otherwise, they would be undefeatable. Nevertheless, they certainly do not make the obvious ones. Great villains cause a genuine trial for the hero, by being on top of their plot.

In an ending inference, we are inclined to state that when evil heart, with strong desire of something, meets intelligence and fights for acquisition of these desires with great determination, the destructive consequences might kill the most precious matter of life - humanism. Most notably, Shakespeare warns that the highest cost of villainy is the loss of one's humanity. And Richard III's last words can make a great sense about the general destiny of villains.

"I shall despair. There is no creature loves me;

And if I die, no soul shall pity me". [9, 5, 3]

As if the genius author once more tries to convince us that a person when becomes the slave of his evil desires like devil deserves not to be loved in a lifetime and not to be cared at all after the death.

\section{References:}

1. Alqaryouti, M., \& Sadeq, A. E. (2016). The Concept of Villain in Shakespeare's Othello. https://doi.org/10.5539/ells.v6n4p75

2. Kumaresan, P. (2012). Claudius and Macbeth: A Comparison between a Villain and a Tragic-Hero. Journal of Literature, Culture and Media Studies, 3(5\&6).

3. Lacerva, P. A. (1971). Shakespeare's' Rational'Villains in Relation to Right Reason.

4. Islam, M. S. (2010). Nature of Evil in Macbeth. Arts Faculty Journal, 185-194. https://doi.org/10.3329/afj.v4i0.12940

5. Öztürk, S. (2009). Two notorious villains in two famous literary works: satan in paradise lost and macbeth in macbeth. Journal of International Social Research, 2(9).

6. Parker, J. (2006). Shakespeare and the Geneva Bible: The Story of King Saul as a Source for Macbeth. Tennessee Philological Bulletin, 43, 6-23.

7. Sherr-Ziarko, E. A. (2011). Confronting Evil on the Stage: The Immoral Villain as a Moral Figure.

8. Bell, S. C., \& Burney, F. Hilton, John 1804-78. https://doi.org/10.1007/978-1-4614-11147_16

9. Shakespeare, W., Wells, S., \& Taylor, G. (2005). The Oxford Shakespeare: the complete works (p. 1150). Oxford: Oxford University Press. 


\section{Список литературы:}

1. Alqaryouti M., Sadeq A. E. The Concept of Villain in Shakespeare's Othello. 2016. https://doi.org/10.5539/ells.v6n4p75

2. Kumaresan P. et al. Claudius and Macbeth: A Comparison between a Villain and a TragicHero // Journal of Literature, Culture and Media Studies. 2012. Vol. 3. №5\&6.

3. Lacerva P. A. Shakespeare's' Rational'Villains in Relation to Right Reason. 1971.

4. Islam M. S. Nature of Evil in Macbeth // Arts Faculty Journal. 2010. P. 185-194. https://doi.org/10.3329/afj.v4i0.12940

5. Öztürk S. Two notorious villains in two famous literary works: satan in paradise lost and macbeth in macbeth // Journal of International Social Research. 2009. Vol. 2. №9.

6. Parker J. Shakespeare and the Geneva Bible: The Story of King Saul as a Source for Macbeth // Tennessee Philological Bulletin. 2006. Vol. 43. P. 6-23.

7. Sherr-Ziarko E. A. Confronting Evil on the Stage: The Immoral Villain as a Moral Figure. 2011.

8. Bell S. C., Burney F. Hilton, John 1804-78. https://doi.org/10.1007/978-1-4614-1114-7_16

9. Shakespeare W., Wells S., Taylor G. The Oxford Shakespeare: the complete works. Oxford: Oxford University Press, 2005. P. 1150.

Работа поступила

в редакиию 28.02.2020 г.
Принята к публикациии

05.01.2020 2.

Ссылка для циитирования:

Tursunova M. Comparative Analysis of Intelligent Devil Villains in W. Shakespeare's Tragedies: Macbeth, Julius Caesar and Othello // Бюллетень науки и практики. 2020. Т. 6. №4. С. 527-531. https://doi.org/10.33619/2414-2948/53/63

Cite as (APA):

Tursunova, M. (2020). Comparative Analysis of Intelligent Devil Villains in W. Shakespeare's Tragedies: Macbeth, Julius Caesar and Othello. Bulletin of Science and Practice, 6(4), 527-531. https://doi.org/10.33619/2414-2948/53/63 